\title{
Antibacterial Activity of Lactic Acid Bacteria Isolated from Fermented Ethiopian Traditional Dairy Products against Food Spoilage and Pathogenic Bacterial Strains
}

\author{
Abayeneh Girma $\mathbb{D}$ and Aleka Aemiro \\ Department of Biology, College of Natural and Computational Science, Mekdela Amba University, P.O. Box 32, \\ Tuluawlia, Ethiopia \\ Correspondence should be addressed to Abayeneh Girma; gabayeneh2013@gmail.com
}

Received 2 June 2021; Revised 21 October 2021; Accepted 22 October 2021; Published 9 November 2021

Academic Editor: Alessandro Di Cerbo

Copyright (c) 2021 Abayeneh Girma and Aleka Aemiro. This is an open access article distributed under the Creative Commons Attribution License, which permits unrestricted use, distribution, and reproduction in any medium, provided the original work is properly cited.

\begin{abstract}
Fermented Ethiopian traditional dairy products containing LAB that show antibacterial activities against various food spoilage and pathogenic bacteria have been used for the preservation of fermented dairy products for a long time. However, there are no comprehensive scientific reports on the antibacterial activity of LAB isolated from various fermented dairy products in Pawe Woreda. The objective of the study was to evaluate the antibacterial activity of LAB isolated from traditionally fermented Ethiopian dairy products against spoilage and pathogenic bacteria. Thirty-five samples of fermented dairy products were collected from three cattle-farming areas of Pawe Woreda. A total of $97 \mathrm{LAB}$ were isolated and screened primarily using the perpendicular streak plate method against 3 Gram-positive and 3 Gram-negative bacterial strains. Out of the 97 strains, 10 were active against at least two of the tested bacteria, of which 7 strains were selected for secondary screening by their broad-spectrum antibacterial activities. The seven in vitro antibacterial activities of the extract ranged from 5 to $16 \mathrm{~mm}$ in diameter during the secondary screening. In this study, Z2, Z4, and N2 strains exhibited the highest inhibition zone with broad-spectrum activity against all tested bacteria. The MIC and MBC values range from 0.10 to $0.30 \mu \mathrm{g} / \mu \mathrm{L}$ and 0.20 to $0.50 \mu \mathrm{g} / \mu \mathrm{L}$, respectively. Following morphological, physiological, biochemical, and molecular characteristics, seven potent strains were identified as Lactobacillus acidophilus, Lactobacillus paracasei, Lactobacillus plantarum, Lactobacillus rhamnosus, Leuconostoc mesenteroides, Streptococcus thermophilus, and Lactococcus lactis. According to the findings of this study, Ethiopian fermented dairy products were the most potent source of bioactive compounds with potential effects against food spoilage and pathogenic bacterial strains.
\end{abstract}

\section{Introduction}

Pathogenic and spoilage microbes must be controlled in a variety of foods to ensure food quality and safety. Biopreservation has recently become a popular subject [1]. Applying native microflora and their antimicrobial products is an alternative technique to chemical additives and spices for preventing changes in organoleptic and nutritional properties of foods [2]. LAB are thought to be beneficial and have long been used as the natural flora in fermented foods. $\mathrm{LAB}$ also saves serious public health problems and economic losses by producing antimicrobial agents such as bacteriocins, diacetyl, organic acids, carbon dioxide, and hydrogen peroxide [3].

Modern food processing is currently confronted with a challenge in that it seeks to prolong the shelf life and protection of foods by chemical means, while customers prefer minimally processed foods that are free of chemical preservatives. This has sparked a lot of interest in so-called "green technology," such as new ways to process and utilize microbial metabolites for biopreservation with minimal processing [4]. LAB are commonly considered to be healthy 
and play an important role in the fermentation and preservation of food and feeds, either as native microflora or as starter cultures added under controlled conditions. LAB preservative effect is primarily due to the processing of organic acids such as lactic, acetic, propionic, and butyric acids which lowers the $\mathrm{pH}$ of the fermented products; as a result, the growth and survival of many harmful bacteria are inhibited [5]. Furthermore, by producing bacteriocins, some strains can aid in the preservation and microbial safety of foods by promoting the microbial and nutritional stability of the final fermented food products [6].

LAB have been researched extensively for market potential, food safety, and health benefits [7]. They are important industrial microorganisms that are used primarily in the dairy industry to make fermented milk products and cheese. The ability of LAB to ferment sugars quickly into various metabolites and provide an effective method for storing fermented food products gives them industrial significance. Besides, Tagg et al. [8] confirmed that the bacteriocins from the widely regarded as safe LAB have attracted a lot of interest as a novel way to combat spoilage and pathogenic bacteria in foodstuff.

Antimicrobial compounds found in microorganisms are discovered through the screening process, which involves detecting and isolating a new microbial product. It encompasses both primary (qualitative) and secondary (quantitative and more probing) screening tests [9]. Primary screening (presence-absence test) allows the detection and isolation of microorganisms that possess potentially interesting industrial applications. Crowded and cross-streak plate methods are often primarily used for screening antimicrobial activity. While promising strains from primary screening are retested with more specialized media and conditions, this is known as secondary screening. In this screening, a new microbial product for clinical application may involve detailed characterization and identification of the strain, purification, and characterization of the antimicrobial product, molecular structure determination of the product for possible chemical modification, and toxicology evaluation $[6,8]$.

LAB produces antimicrobial compounds that are active against a wide range of harmful bacteria, despite greatly varying in chemical structure and mode of action [1, 5]. Bacteriocins, for example, are one class of proteinaceous compounds that form a heterogeneous group with respect to the producing bacterial strains, molecular size, antimicrobial spectrum, stability, physical and chemical properties, and mode of action [3, 6]. Lactostrepcin, nisin, lacticin, bacteriocin, dricin, lactococcin, diplococcin, diacetin, mesenterocin, leucocin, thermophilin, lactacin, acidophilin, acidophilicin, acidocin, acidolin, gassericin, reutericyclin, reutericin, caseicin, plantaricin, bulgarican, lactobacilli, enteroccin, enteroccin, bifidocin, and pediocin are some of the well-known antimicrobial compounds (bacteriocins) produced by different genera of LAB such as Lactococcus, Leuconostoc, Streptococcus, Lactobacillus, Enterococcus, Bifidobacterium, and Pediococcus genus $[5,6,8,9]$. The use of these inhibitory substances in extending the shelf life of milk and milk products through inhibiting and killing food spoilage and pathogenic bacterial strains has provided successful results across the world. To the best of our knowledge, no significant information on the typical fermentative microflora that produces antibacterial substances exists in Pawe Woreda. The aim of this work was to look for antibacterial activity among LAB found in fermented Ethiopian traditional dairy products.

\section{Materials and Methods}

2.1. Description of the Study Area. The study was conducted in Pawe Woreda, Metekel Zone of Benishangul Gumuz regional state, Northwest Ethiopia, located $400 \mathrm{~km}$ from the regional town Assosa and $575 \mathrm{~km}$ away from Addis Ababa, the capital city of Ethiopia. Its geographical coordinates are located at a latitude/longitude of $11^{\circ} 19^{\prime} \mathrm{N}$ and $36^{\circ} 24^{\prime \prime} \mathrm{E}$ with an elevation range of 980-1250 meters above sea level. Its annual minimum and maximum temperatures are 19.5 and $37.7^{\circ} \mathrm{C}$, respectively, and it receives an annual rainfall ranging from 900 to $1587 \mathrm{~mm}$. The Woreda covers a total area of 63,450 hectares. The Woreda is divided into 20 Kebeles and has 12267 households with 50220 inhabitants, 25153 of whom are males and 25067 of whom are females. The farming system of the Woreda is characterized by a mixed crop-livestock farming system that produces different fermented (Ergo, Ayib, Metata Ayib, and other) dairy products from cow milk [10].

2.2. Collection of Samples. A total of 35 samples of fermented Ethiopian dairy products ("Ergo," "Metata Ayib," and "Ayib") were collected randomly from three cattle-farming areas (Pawe town, Village 130, and Village 4) of Pawe Woreda households. Of 35 total fermented Ethiopian dairy products, 20, 10, and 5 samples were "Ergo," "Metata Ayib," and "Ayib," respectively. All samples were collected in sterile polyethylene bags, well-labeled, and transferred to the Microbiology Laboratory of Pawe Agricultural Research Center, with the help of an icebox. The samples were immediately processed after arrival.

2.3. Isolation, Purification, and Growth Conditions of the Isolates. Ten grams of each ("Ergo," " Metata Ayib," and "Ayib") Ethiopian fermented dairy product samples was well-homogenized with $90 \mathrm{ml}$ of sterile physiological $(0.85 \%$ $\mathrm{NaCl} \mathrm{w/v)} \mathrm{saline} \mathrm{solution} \mathrm{for} 30 \mathrm{sec}$ with the help of a stomacher lab-blender (Stomacher ${ }^{\circledR} 400$ Circulator, UK); then, the resulting homogenate was serially diluted up to $10^{-8}$ using sterile normal $(0.85 \% \mathrm{NaCl} \mathrm{w} / \mathrm{v})$ saline solution. From $10^{-5}$ to $10^{-8}$ dilutions, $0.1 \mathrm{~mL}$ was taken and spread on the prepared De Man Rogosa and Sharpe (MRS) agar medium (Merck, Germany) with the help of a bent glass spreader [11]. All plates were incubated in triplicate at $30^{\circ} \mathrm{C}$ for $48-72 \mathrm{~h}$ in an anaerobic jar (BD Gas Pak ${ }^{\mathrm{TM}} 150$ Systems, USA). Representative pure colonies were subcultured on MRS slant and kept at $4^{\circ} \mathrm{C}$ for further analysis and characterization tests. 
2.4. Food Spoilage and Pathogenic Bacterial Strain Collection. Staphylococcus aureus (ATCC ${ }^{\circledast}$ 29213), Bacillus cereus (ATCC $^{\oplus}$ 11778), Salmonella enteritidis $\left(\right.$ ATCC $\left.^{\oplus} 13076\right)$, Listeria monocytogenes (ATCC ${ }^{\circledast}$ 7644), Pseudomonas aeruginosa (ATCC ${ }^{\oplus}$ 27853), and Escherichia coli (ATCC ${ }^{\otimes}$ 8739) were used as test organisms which are the most common food spoilage and pathogenic bacteria.

2.5. Standardization and Inoculum Preparation for Antibacterial Activity Test. $0.50 \mathrm{~mL}(1.175$ percent $\mathrm{w} / \mathrm{v})$ dehydrated barium chloride $\left(\mathrm{BaCl}_{2} \bullet 2 \mathrm{H}_{2} \mathrm{O}\right)$ solution was mixed with $99.50 \mathrm{~mL}\left(1\right.$ percent v/v) sulfuric acid $\left(\mathrm{H}_{2} \mathrm{SO}_{4}\right)$ to make a $0.5 \mathrm{McFarland}$ standard solution. The inoculum suspension was prepared by aliquoting the turbidity standard solution into identical test tubes. The absorbance of the prepared 0.5 McFarland standard solution was also confirmed spectrophotometrically to be 0.08 to 0.12 at $625 \mathrm{~nm}$. The standard solution tube was tightly sealed and kept at room temperature to avoid evaporation and illumination. The turbidity standard tube was combined with a vortex mixer to achieve a uniform turbid appearance before being compared to the bacterial suspension [12].

From a $24 \mathrm{~h}$ pure agar culture, 4-5 morphologically identical bacterial colonies were suspended in $5 \mathrm{~mL}$ sterile nutrient broth (HiMedia, India) and compared to that of 0.5 McFarland standard solution, which is roughly equivalent to $1.5 \times 10^{8} \mathrm{CFU} / \mathrm{mL}$. After adjusting the turbidity, a sterile cotton swab was dipped in the suspension and streaked over the entire surface of the prepared Muller-Hinton Agar (MHA) medium (HiMedia, India) by rotating the plate at a $60^{\circ}$ angle to ensure even inoculum distribution [12].

2.6. Primary Screening. The antibacterial activities of the $\mathrm{LAB}$ isolated from the fermented Ethiopian dairy product samples were primarily screened against spoilage and pathogenic bacterial strains using the perpendicular streak plate method. The isolates to be screened for antibiotic production were streaked horizontally at the diameter of the MHA medium and incubated at $30^{\circ} \mathrm{C}$ for $24-48 \mathrm{~h}[6,13]$. Following incubation, 0.5 McFarland standard adjusted bacterial strains, namely, S. aureus (ATCC ${ }^{\oplus} 29213$ ), B. cereus (ATCC $^{\oplus}$ 11778), S. enteritidis $\left(\right.$ ATCC $^{\oplus}$ 13076), L. monocytogenes (ATCC ${ }^{\circledR} 7644$ ), P. aeruginosa (ATCC ${ }^{\circledR}$ 27853), and E. coli (ATCC ${ }^{\circledast}$ 8739), were streaked vertically at $90^{\circ}$ angle very close to the screened one from left to right, respectively. The plates were then further incubated at $37^{\circ} \mathrm{C}$ for $24 \mathrm{~h}$, and zones of inhibition were indicated between the antibiotic-producing isolates and the test organisms that were considered as positive for antibiotic production. The positive isolates were then selected based on a wide spectrum of activity against the tested bacterial strains. The isolates were maintained in MRS slants and kept at $4^{\circ} \mathrm{C}$ for further antibacterial compound extraction, secondary screening, and characterization tests.

2.7. Antibacterial Compound Extraction from $L A B$. The active and broad-spectrum LAB strains were subjected to the submerged state fermentation method to produce crude extracts. Fresh cultures of each antibacterial compoundproducing isolate were inoculated separately in a $250 \mathrm{~mL}$ Erlenmeyer flask containing $100 \mathrm{~mL}$ MRS broth in anaerobic conditions at $30^{\circ} \mathrm{C}$ for $72 \mathrm{~h}$. After incubation, each sample was centrifuged at $6,000 \mathrm{rpm}$ for $15 \mathrm{~min}$ at $4^{\circ} \mathrm{C}$ to obtain cellfree culture supernatant (CFS). The cell-free solution obtained was mixed with ammonium sulfate (70\% saturation). The mixture was subjected to shaking on a rotary shaker at $250 \mathrm{rpm}$ for $2 \mathrm{~h}$ at $4^{\circ} \mathrm{C}$. Finally, the organic phase was separated from the aqueous phase by using a separating funnel and concentrated to dryness under vacuum using a rotary evaporator at a temperature of $50^{\circ} \mathrm{C}[14,15]$.

2.8. Secondary Screening. Antibacterial activities of the LAB strains were evaluated against spoilage and pathogenic bacterial strains using the disc diffusion method as described by Kirby-Bauer with some modifications [16]. After adjusting the turbidity to that of $1.5 \times 10^{8} \mathrm{CFU} / \mathrm{mL}$, bacterial strains, namely, S. aureus (ATCC ${ }^{\circledast} 29213$ ), B. cereus (ATCC ${ }^{\circledast}$ 11778), S. enteritidis (ATCC ${ }^{\oplus}$ 13076), L. monocytogenes (ATCC $^{\oplus}$ 7644), P. aeruginosa $\left(\right.$ ATCC $^{\oplus} 27853$ ), and E. coli (ATCC $^{\oplus} 8739$ ), were swabbed uniformly on sterile MHA medium using a sterile cotton swab. Sterile $6 \mathrm{~mm}$ diameter paper discs were impregnated with $10 \mu \mathrm{L}$ of each extract. The inoculated plates and the impregnated discs were left for 5-10 min to absorb the moisture and to dry the disc. The impregnated discs were introduced to the upper layer of the seeded agar plate and incubated at $37^{\circ} \mathrm{C}$ for $24 \mathrm{~h}$. The antibacterial activities of the CFS were compared with the known antibiotic Gentamicin $(10 \mu \mathrm{g} / \mathrm{disc})$ as a positive control and distilled water $(10 \mu \mathrm{l} / \mathrm{disc})$ as a negative control. The diameter of the inhibition zone $(\mathrm{mm})$ on the surface of the plates was measured to determine the antibacterial activity, and the results were recorded as mean $\pm \mathrm{SD}$ after three repeats of the experiment [17].

2.9. Characterization of Strains and Their Antimicrobial Compounds. The purified cultures were characterized following standard morphological, physiological, biochemical, and molecular tests. Gram staining, spore staining, catalase test, oxidase test, motility test, growth at different carbon sources, temperature, $\mathrm{pH}$, and sodium chloride concentrations were performed to characterize the LAB strains [18]. The pure isolate was stored at $-80^{\circ} \mathrm{C}$ in MRS broth with glycerol before use. LAB were identified using a 16s rRNA gene with the primers 27F (5-AGAGTTTGATCCTGGCTCAG-3') and 1492R (5'-TACGGYTACCTTGTTACGACTT-3 ${ }^{\prime}$ ) [9, 19]. Sequencing was performed in the EzTaxon-e database with a sequencematching program.

Different enzymes such as proteinase $\mathrm{K}$, pepsin, $\alpha$-amylase, and lysozyme (BIO BASIC Canada INC) were added to the CFS of the selected strains (Z1, Z2, Z3, Z4, M1, $\mathrm{F} 2$, and N2) to evaluate their effect on inhibitory substances. The CFS obtained from the selected strains were treated with catalase in a water bath at $25^{\circ} \mathrm{C}$ for 1 hour, filtered, and stored at $4^{\circ} \mathrm{C}$ for further analysis. Calcium 
chloride buffer was added at $1 \mathrm{mg} / \mathrm{mL}$ enzymes, of proteinase $\mathrm{K}$, papain, $\alpha$-amylase, and lysozyme. Then, the solutions were filter sterilized and set at $37^{\circ} \mathrm{C}$ for $3 \mathrm{~h}$, and the mixture was boiled for $3 \mathrm{~min}$ to inactivate the enzymes. Bacteriostatic and bactericidal effects were analyzed using the disc diffusion method. Finally, the activity of the residual was determined by observing the presence of an inhibition zone $[9,19,20]$.

The antibacterial activity of the substances was also evaluated after treatment under various conditions. The influences of temperature on the antimicrobial activity of the CFS were estimated by heating at $45,65,85$, and $100^{\circ} \mathrm{C}$ for $30 \mathrm{~min}$. The effect of $\mathrm{pH}$ on the CFS antibacterial activity was determined by adjusting the $\mathrm{pH}$ of the CFS to $2,4,6,8$, and 10 , using $1 \mathrm{~N} \mathrm{HCl}, 1 \mathrm{~N} \mathrm{NaOH}$, and a $\mathrm{pH}$ meter. The CFS was exposed to $30^{\circ} \mathrm{C}$ for $1 \mathrm{~h}$, and the samples were readjusted to pH 6.0 and the activity was determined. To observe the effect of organic solvent on the bioactivity of CFS, methanol and ethanol solvents were added to the CFS at $1: 9(\mathrm{vol} / \mathrm{vol})$ and placed at $30^{\circ} \mathrm{C}$ for $30 \mathrm{~min}$. $1 \%(\mathrm{w} / \mathrm{t})$ sodium citrate and potassium chloride were added and mixed into the CFS to observe the effect of the additives on the antibacterial activity. All of the treated solutions of the antibacterial experiments were incubated for $24 \mathrm{~h}$ at $37^{\circ} \mathrm{C}$ by using the disc diffusion method. The inhibitory activity of the residual was determined by observing their zone of inhibition. Sterile water and untreated CFS were used as negative and positive controls, respectively $[19,20]$.

2.10. MIC and MBC Determination. The minimum inhibitory concentration (MIC) and minimum bactericidal concentration $(\mathrm{MBC})$ were determined by the broth twofold serial dilution method [21]. Twelve screw-capped test tubes were picked, and a volume of $1 \mu \mathrm{L}$ of nutrient broth was dispensed into test tubes $1-10$ and $2 \mu \mathrm{L}$ into test tube 11 (negative control). $1 \mu \mathrm{L}$ of the cell-free extract was added to test tube 1 , mixed well, and transferred to test tube 2 , and this process was continued serially up to test tube 10 by mixing and changing the micropipette tips at each dilution, and $2 \mu \mathrm{L}$ was added to test tube 12 (positive control). $1 \mu \mathrm{L}$ of standardized $\left(1.5 \times 10^{8} \mathrm{CFU} / \mathrm{mL}\right)$ inoculum was added to test tubes $1-10$ and incubated at $37^{\circ} \mathrm{C}$ for $24 \mathrm{~h}$. After incubation, the MIC value was determined by observing the growth of bacteria in the test tube. From the above test tubes with no turbidity, $1 \mu \mathrm{L}$ was spread on the surface of MHA plates. After incubation at $37^{\circ} \mathrm{C}$ for $24 \mathrm{~h}$, the colonies were observed and the $\mathrm{MBC}$ was determined.

2.11. Statistical Analysis. Three independent experiments were performed. All data were analyzed by one-way ANOVA using statistical package for social science (SPSS) version, 23. Differences among means were tested for significance $(P<0.05)$ by Duncan's multiple range test.

\section{Results}

3.1. Isolation and Characterization of LAB in Ethiopian Fermented Dairy Products. A total of ninety-seven LAB isolates were characterized and grouped into six genus levels following morphological, physiological, and biochemical characteristics as presented in Table 1.33 (34.0\%) of the six genera were Lactobacillus, 20 (20.6\%) Lactococcus, 17 (17.5\%) Leuconostoc, 12 (12.4\%) Pediococcus, 10 (10.3\%) Streptococcus, and 5 (5.2\%) Enterococcus spp. Lactobacillus $33(34.0 \%)$ was the most dominant while Enterococcus 5 (5.2\%) was the least occurring species. These LAB were isolated from thirty-five Ethiopian fermented dairy product samples collected from the residents of Pawe Woreda. From these isolates, 48 (49.5\%) from Pawe town, 32 (33.0\%) from Village 130, and 17 (17.5\%) from Village 4 were found. Out of $97 \mathrm{LAB}$ isolates, 57 (58.8\%), 30 (30.9\%), and 10 (10.3\%) were obtained from "Ergo," "Metata Ayib," and "Ayib," respectively. All isolates were grown under anaerobic conditions. Gram-positive, catalase, oxidase, and spore negative and nonmotile characteristics were observed in all isolates. During microscopic observation, the majority (66\%) was cocci, and the remaining (34\%) were rod-shaped LAB. Except for Streptococcus and Pediococcus spp., all isolates produce carbon dioxide from glucose metabolism. All isolates ferment lactose as a sole source of carbon while variations were observed during fermentation of other (glucose, sucrose, xylose, melibiose, raffinose, and sorbitol) carbon sources. All isolates were grown well between 15 and $30^{\circ} \mathrm{C}$ while fluctuations were observed in isolates from 10 to $45^{\circ} \mathrm{C}$ tolerance. All isolates grew well in the prepared medium with $\mathrm{pH}$ levels of 2, 4, and 5. The majority of the isolates were grown in a medium supplemented with 2 and $4 \%$ sodium chloride. However, almost all of the isolates were not grown well on a $6.5 \%$ salt medium.

The sequences of $16 \mathrm{~S}$ rRNA gene products of the seven strains with antibacterial activities result were observed between 100 and $200 \mathrm{bp}$ of ladder sequence and compared with the EzTaxon-e database and gave $100 \%$ similarity to Lactobacillus acidophilus, Lactobacillus plantarum, Lactobacillus rhamnosus, and Lactococcus lactis while 99\% homology was observed for Lactobacillus paracasei, Leuconostoc mesenteroides, and Streptococcus thermophiles (Supplementary data 1 and Table 2).

The CFS was treated with different enzymes (proteinase $\mathrm{K}$, papain, $\alpha$-amylase, and lysozyme), and their antibacterial effects were examined after $24 \mathrm{~h}$ of incubation at $37^{\circ} \mathrm{C}$. The antibacterial effect of the CFS of different LAB strains was reduced after treatment with proteinase $\mathrm{K}$ and papain, while the lysozyme and $\alpha$-amylase enzymes had no effect on the antagonistic activity of the CFS of the LAB strains (Table 3).

Low and medium temperatures had no effect on the antibacterial activity of the CFS. However, high temperatures $\left(100^{\circ} \mathrm{C}\right)$ had some effect. An acidic environment $(\mathrm{pH}$ range of 2-6) is preferable for the inhibitory effect of the CFS. Ethanol was a good solvent that enhanced the antibacterial effects of the CFS as compared to methanol. The seven LAB strains CFS were treated with additives, such as sodium citrate and potassium chloride, to verify the effect of food additives and other chemicals on the antibacterial substances of LAB. Sodium citrate was an effective additive with LAB strain CFS as compared to potassium chloride (Table 4). 
TABLE 1: Morphological, physiological, and biochemical characteristics of the isolated LAB from fermented Ethiopian dairy products of Pawe Woreda.

\begin{tabular}{|c|c|c|c|c|c|c|}
\hline Tests/isolate codes & G & $\mathrm{Z}$ & M & $\mathrm{F}$ & $\mathrm{N}$ & $\mathrm{R}$ \\
\hline Cell shape & Cocci & Rod & Cocci & Cocci & Cocci & Cocci \\
\hline Gram staining & + & + & + & + & + & + \\
\hline Spore staining & - & - & - & - & - & - \\
\hline Motility & - & - & - & - & - & - \\
\hline Catalase test & - & - & - & - & - & - \\
\hline Oxidase test & - & - & - & - & - & - \\
\hline $\mathrm{CO}_{2}$ from glucose & + & + & + & - & + & - \\
\hline \multicolumn{7}{|l|}{ Fermentation of } \\
\hline Glucose & - & + & + & + & + & - \\
\hline Lactose & + & + & + & + & + & + \\
\hline Sucrose & + & + & \pm & \pm & - & + \\
\hline Xylose & + & \pm & \pm & \pm & \pm & + \\
\hline Melibiose & \pm & \pm & - & - & - & - \\
\hline Raffinose & + & - & - & - & - & \pm \\
\hline Sorbitol & - & + & \pm & - & - & \pm \\
\hline \multicolumn{7}{|l|}{ Growth at $\mathrm{d} / \mathrm{t}\left(\mathrm{T}^{\mathrm{o}}\right)$} \\
\hline $10^{\circ} \mathrm{C}$ & - & - & - & - & \pm & - \\
\hline $15^{\circ} \mathrm{C}$ & + & + & + & + & + & + \\
\hline $45^{\circ} \mathrm{C}$ & \pm & \pm & \pm & \pm & \pm & \pm \\
\hline \multicolumn{7}{|l|}{ Growth at $\mathrm{d} / \mathrm{t}(\mathrm{pH})$} \\
\hline 2 & + & + & + & + & + & + \\
\hline 3 & + & + & + & + & + & + \\
\hline 5 & + & + & + & + & + & + \\
\hline \multicolumn{7}{|c|}{ Growth at $\mathrm{d} / \mathrm{t}(\mathrm{NaCl})$} \\
\hline $2 \%$ & + & - & + & + & \pm & + \\
\hline $4 \%$ & + & \pm & \pm & + & + & + \\
\hline $6.5 \%$ & \pm & - & - & - & - & - \\
\hline
\end{tabular}

TABLE 2: Identification of LAB strains through 16S rRNA gene analysis.

\begin{tabular}{lcc}
\hline Strain & Identified strains & \% of similarity \\
\hline Z1 & Lactobacillus acidophilus & 100 \\
Z2 & Lactobacillus paracasei & 99 \\
Z3 & Lactobacillus plantarum & 100 \\
Z4 & Lactobacillus rhamnosus & 100 \\
M1 & Leuconostoc mesenteroides & 99 \\
F2 & Streptococcus thermophilus & 99 \\
N2 & Lactococcus lactis & 100 \\
\hline
\end{tabular}

TABLE 3: Effect of different enzymes on the antibacterial activities of metabolites of the stains.

\begin{tabular}{lccccccc}
\hline Enzymes & Z1 & Z2 & Z3 & Z4 & M1 & F2 & N2 \\
\hline Proteinase K & + & + & + & + & + & + & + \\
Papain & + & + & + & + & + & + & + \\
$\alpha$-Amylase & ++ & ++ & ++ & ++ & ++ & ++ & ++ \\
Lysozyme & ++ & ++ & ++ & ++ & ++ & ++ & ++ \\
\hline
\end{tabular}

+: inhibition zone $<7 \mathrm{~mm}$; ++: inhibition zone $>10 \mathrm{~mm}$.

3.2. In Vitro Primary and Secondary Screening of LAB Strains. Out of $97 \mathrm{LAB}$ isolates subjected to primary screening, 10 strains showed varying levels of inhibitory effects against the six test organisms as presented in Table 5. Out of 10 LAB isolates, 7 strains were found to have potent antibacterial activity against Gram-positive and Gram-negative food spillage and pathogenic organisms, while 3 of the strains were active only on Gram-positive bacterial strains, and many of the potent strains were isolated from the "Ergo" and "Metata Ayib" samples. During the primary screening, the highest inhibition zones with broad-spectrum activities were recorded from three (Z2, Z4, and N2) LAB strains.

The cell-free extracts of the seven potent and widespectrum LAB strains (Z1, Z2, Z3, Z4, M1, F2, and N2) were subjected to secondary screening using the disc diffusion method as shown in Table 6 and Supplementary data 2. The in vitro antibacterial activities ranged from 5 to $16 \mathrm{~mm}$ in diameter. During the secondary screening, compared to the remaining strains, the results of this study revealed that $\mathrm{Z} 2$, Z4, and N2 showed the highest inhibition zones with the broad-spectrum activity of all tested food spoilage and pathogenic bacterial strains, as presented in Supplementary data 2 . In the antibacterial screening, all of the seven LAB strains were active against Gram-positive ( $S$. aureus and $B$. cereus) bacterial strains, while variations were observed toward Gram-negative food spoilage and pathogenic ( $S$. enteritidis, L. monocytogenes, $P$. aeruginosa, and E. coli) indicator organisms as presented in Table 6.

3.3. MIC and MBC of the LAB Strains. The MIC and MBC of the seven broad-spectrum antibacterial compounds producing LAB strains were done against six (3 Gram-positive and 3 Gram-negative) food spoilage and pathogenic indicator bacterial strains. The MIC value ranges from 0.10 to 
TABLE 4: Effect of temperature, pH, organic solvents, and additives on the activity of CFS

\begin{tabular}{|c|c|c|c|c|c|c|c|}
\hline Concentrations used for treatment & $\mathrm{Z1}$ & $\mathrm{Z} 2$ & $\mathrm{Z3}$ & $\mathrm{Z} 4$ & M1 & F2 & $\mathrm{N} 2$ \\
\hline \multicolumn{8}{|l|}{ Temperature/time } \\
\hline $45^{\circ} \mathrm{C} / 30 \mathrm{~min}$ & ++ & ++ & ++ & ++ & ++ & ++ & ++ \\
\hline $65^{\circ} \mathrm{C} / 30 \mathrm{~min}$ & ++ & ++ & ++ & ++ & ++ & ++ & ++ \\
\hline $85^{\circ} \mathrm{C} / 30 \mathrm{~min}$ & ++ & ++ & ++ & ++ & ++ & ++ & ++ \\
\hline $100^{\circ} \mathrm{C} / 30 \mathrm{~min}$ & - & ++ & - & ++ & ++ & - & ++ \\
\hline \multicolumn{8}{|l|}{$\mathrm{pH}$} \\
\hline $2 / 30 \mathrm{~min}$ & ++ & ++ & ++ & ++ & ++ & ++ & ++ \\
\hline $4 / 30 \mathrm{~min}$ & ++ & ++ & ++ & ++ & ++ & ++ & ++ \\
\hline $6 / 30 \min$ & ++ & ++ & ++ & ++ & ++ & ++ & ++ \\
\hline $8 / 30 \mathrm{~min}$ & + & ++ & + & ++ & + & + & ++ \\
\hline $10 / 30 \mathrm{~min}$ & - & - & - & - & - & - & - \\
\hline \multicolumn{8}{|l|}{ Organic solvent } \\
\hline Methanol 10\% (vol/vol) /30 min & + & ++ & + & ++ & ++ & + & ++ \\
\hline Ethanol 10\% (vol/vol) $/ 30 \mathrm{~min}$ & ++ & ++ & ++ & ++ & ++ & ++ & ++ \\
\hline \multicolumn{8}{|l|}{ Additive } \\
\hline Potassium chloride $1 \%(\mathrm{wt} / \mathrm{vol}) / 30 \mathrm{~min}$ & + & ++ & + & ++ & ++ & + & ++ \\
\hline Sodium citrate $1 \%(\mathrm{wt} / \mathrm{vol}) / 30 \mathrm{~min}$ & ++ & ++ & ++ & ++ & ++ & + & ++ \\
\hline
\end{tabular}

TABLE 5: Primary screening of LAB strains for antibacterial activity evaluation against food spoilage and pathogenic bacterial strains.

\begin{tabular}{|c|c|c|c|c|c|c|}
\hline $\begin{array}{l}\text { LAB } \\
\text { strains }\end{array}$ & $\begin{array}{c}\text { S. aureus } \\
\left(\text { ATCC }^{\circledast} 29213\right)\end{array}$ & $\begin{array}{c}\text { B. cereus } \\
\left(\text { ATCC }^{\circledast} 11778\right)\end{array}$ & $\begin{array}{c}\text { S. enteritidis } \\
\left(\text { ATCC }^{\circledast} 13076\right)\end{array}$ & $\begin{array}{l}\text { L. monocytogenes } \\
\left(\text { ATCC }^{\circledast 7} 7644\right)\end{array}$ & $\begin{array}{c}\text { P. aeruginosa } \\
\left.\text { (ATCC }^{\circledR} 27853\right)\end{array}$ & $\begin{array}{c}\text { E. coli }\left(\mathrm{ATCC}^{\oplus}\right. \\
8739)\end{array}$ \\
\hline$\overline{\mathrm{Z} 1}$ & + & + & - & + & - & + \\
\hline $\mathrm{Z} 2$ & ++ & ++ & ++ & ++ & ++ & ++ \\
\hline $\mathrm{Z3}$ & + & + & + & - & - & - \\
\hline $\mathrm{Z} 4$ & ++ & ++ & ++ & ++ & ++ & ++ \\
\hline M1 & ++ & ++ & ++ & ++ & ++ & ++ \\
\hline $\mathrm{F} 1$ & + & + & - & - & - & - \\
\hline F2 & + & + & + & + & + & + \\
\hline N1 & + & + & - & - & - & - \\
\hline N2 & ++ & ++ & ++ & ++ & ++ & ++ \\
\hline $\mathrm{R} 1$ & + & + & - & - & - & - \\
\hline
\end{tabular}

$\div$ no inhibition zone; +: inhibition zone $<7 \mathrm{~mm}$;+t: inhibition zone $>10 \mathrm{~mm}$

TABLE 6: The antibacterial activity of the seven CFS LAB strains against food spoilage and pathogenic bacterial strains using the disc diffusion assay.

\begin{tabular}{|c|c|c|c|c|c|c|}
\hline $\begin{array}{l}\mathrm{LAB} \\
\text { strains }\end{array}$ & $\begin{array}{c}\text { S. aureus } \\
\text { (ATCC }^{\circledast} \text { 29213) }\end{array}$ & $\begin{array}{c}\text { B. cereus } \\
\left.\text { (ATCC }^{\circledast} 11778\right)\end{array}$ & $\begin{array}{c}\text { S. enteritidis } \\
\left(\text { ATCC }^{\circledast} 13076\right)\end{array}$ & $\begin{array}{l}\text { L. monocytogenes } \\
\left(\text { ATCC }^{\circledast 7} 7644\right)\end{array}$ & $\begin{array}{c}\text { P. aeruginosa } \\
\left.\text { (ATCC }^{\circledast} 27853\right)\end{array}$ & $\begin{array}{c}\text { E. coli }\left(\mathrm{ATCC}^{ब}\right. \\
8739)\end{array}$ \\
\hline$Z 1 \pm S E$ & $8.40 \pm 0.5^{\mathrm{a}}$ & $9.60 \pm 0.7^{b}$ & ND & $8.80 \pm 0.7^{b}$ & ND & $9.70 \pm 1.4^{\mathrm{c}}$ \\
\hline$Z 2 \pm S E$ & $16.0 \pm 0.3^{\mathrm{a}}$ & $14.0 \pm 0.4^{\mathrm{a}}$ & $12.0 \pm 0.8^{\mathrm{a}}$ & $13.0 \pm 1.4^{\mathrm{c}}$ & $12.5 \pm 1.5^{\mathrm{c}}$ & $13.0 \pm 0.7^{\mathrm{a}}$ \\
\hline $\mathrm{Z} 3 \pm \mathrm{SE}$ & $10.0 \pm 0.7^{\mathrm{a}}$ & $11.0 \pm 0.3^{b}$ & $10.3 \pm 1.0^{\mathrm{b}}$ & ND & ND & ND \\
\hline$Z 4 \pm S E$ & $15.5 \pm 1.2^{\mathrm{a}}$ & $16.0 \pm 0.6^{\mathrm{a}}$ & $15.0 \pm 1.3^{\mathrm{c}}$ & $14.0 \pm 1.2^{\mathrm{c}}$ & $16.4 \pm 1.0^{\mathrm{b}}$ & $15.3 \pm 1.5^{\mathrm{c}}$ \\
\hline$M 1 \pm \mathrm{SE}$ & $12.0 \pm 0.7^{\mathrm{b}}$ & $11.5 \pm 1.4^{\mathrm{b}}$ & $12.6 \pm 0.7^{\mathrm{b}}$ & $12.0 \pm 0.5^{\mathrm{a}}$ & $11.7 \pm 1.4^{\mathrm{b}}$ & $12.5 \pm 0.7^{\mathrm{b}}$ \\
\hline$F 2 \pm S E$ & $8.30 \pm 1.5^{\mathrm{a}}$ & $9.80 \pm 1.0^{\mathrm{a}}$ & $5.80 \pm 0.9^{\mathrm{b}}$ & $5.50 \pm 0.9^{b}$ & $9.50 \pm 0.5^{\mathrm{a}}$ & $8.50 \pm 1.0^{\mathrm{b}}$ \\
\hline$N 2 \pm \mathrm{SE}$ & $15.5 \pm 0.4^{\mathrm{a}}$ & $16.0 \pm 0.5^{\mathrm{b}}$ & $14.0 \pm 0.9^{\mathrm{b}}$ & $14.4 \pm 0.6^{\mathrm{a}}$ & $16.0 \pm 0.2^{\mathrm{a}}$ & $13.6 \pm 0.7^{\mathrm{a}}$ \\
\hline $\mathrm{CN} \pm \mathrm{SE}$ & $24.3 \pm 1.0^{\mathrm{b}}$ & $26.0 \pm 0.4^{\mathrm{b}}$ & $20.8 \pm 1.2^{\mathrm{c}}$ & $19.0 \pm 1.5^{\mathrm{c}}$ & $18.6 \pm 1.0^{c}$ & $22.0 \pm 0.5^{\mathrm{a}}$ \\
\hline $\mathrm{DW} \pm \mathrm{SE}$ & ND & ND & ND & ND & ND & ND \\
\hline
\end{tabular}

$\mathrm{CN}=$ Gentamicin $(10 \mu \mathrm{g} / \mathrm{disc}$ ) (positive control); $\mathrm{DW}=$ distilled water (negative control); $\mathrm{ND}$ = not detected. Data are average of triplicates; numbers followed by the same letter superscripts in the same row do not vary significantly by Duncan's multiple range test at $p<0.05$; SE: standard error.

$0.30 \mu \mathrm{g} / \mu \mathrm{L}$ while the MBC value ranges from 0.20 to $0.50 \mu \mathrm{g} /$ $\mu$ L. P. aeruginosa (ATCC ${ }^{\circledR} 27853$ ) and L. monocytogenes $\left(\mathrm{ATCC}^{\otimes} 7644\right)$ required high $\mu \mathrm{g} / \mu \mathrm{L}$ cell-free extract to inhibit and kill as compared to the other food spoilage and pathogenic indicator organisms as presented in Table 7. Compared to Gram-negatives, Gram-positive food spoilage and pathogenic bacterial strains require fewer milligrams per milliliter to inhibit or kill by antibacterial producing LAB cell-free extracts. The extracts of Z2, Z4, and N2 LAB strains exhibited excellent inhibitory and bactericidal activity against both Gram-positive and Gram-negative test organisms. 
TABLE 7: The MIC and MBC of broad-spectrum extracts of LAB strains $(\mu \mathrm{g} / \mu \mathrm{L})$ against food spoilage and pathogenic bacterial strains.

\begin{tabular}{|c|c|c|c|c|c|c|c|c|c|c|c|c|}
\hline \multicolumn{7}{|c|}{ MIC } & \multicolumn{6}{|c|}{$\mathrm{MBC}$} \\
\hline Strains & $\mathrm{Sa}$ & $\mathrm{Bc}$ & $\mathrm{Se}$ & $\mathrm{Lm}$ & $\mathrm{Pa}$ & Ec & $\mathrm{Sa}$ & $\mathrm{Bc}$ & $\mathrm{Se}$ & $\mathrm{Lm}$ & $\mathrm{Pa}$ & Ec \\
\hline $\mathrm{Z1}$ & 0.10 & 0.10 & - & 0.30 & - & 0.15 & 0.30 & 0.20 & - & 0.50 & - & 0.30 \\
\hline $\mathrm{Z} 2$ & 0.10 & 0.10 & 0.10 & 0.15 & 0.20 & 0.10 & 0.20 & 0.20 & 0.20 & 0.30 & 0.40 & 0.20 \\
\hline $\mathrm{Z3}$ & 0.20 & 0.10 & 0.30 & - & - & - & 0.50 & 0.30 & 0.50 & - & - & - \\
\hline $\mathrm{Z} 4$ & 0.10 & 0.10 & 0.15 & 0.20 & 0.20 & 0.10 & 0.20 & 0.20 & 0.30 & 0.40 & 0.40 & 0.20 \\
\hline M1 & 0.20 & 0.10 & 0.20 & 0.30 & - & 0.15 & 0.30 & 0.20 & 0.30 & 0.50 & - & 0.30 \\
\hline $\mathrm{F} 2$ & 0.30 & 0.20 & - & 0.30 & 0.30 & 0.20 & 0.50 & 0.40 & - & 0.50 & 0.50 & 0.40 \\
\hline N2 & 0.10 & 0.10 & 0.20 & 0.20 & 0.20 & 0.10 & 0.20 & 0.20 & 0.30 & 0.40 & 0.40 & 0.20 \\
\hline
\end{tabular}

Keys: Sa: S. aureus (ATCC ${ }^{\oplus}$ 29213); Bc: B. cereus (ATCC ${ }^{\oplus}$ 11778); Se: S. enteritidis (ATCC ${ }^{\oplus}$ 13076); Lm: L. monocytogenes (ATCC ${ }^{\oplus}$ 7644); Pa: P. aeruginosa (ATCC $^{\oplus}$ 27853); Ec: E. coli (ATCC ${ }^{\oplus}$ 8739);-: not tested.

\section{Discussion}

Food-borne human pathogens are reemerging and emerging as a major concern and a growing global public health challenge, especially in developing countries like Ethiopia. Food-borne diseases are known to cause a large number of adult illnesses and fatalities; more crucially, they are known to kill a substantial number of children every day as sources of acute diarrheal disorders [22]. Finding new antibacterial medicines for the treatment of pathogens from microorganisms such as LAB is thus a fundamental and critical issue. In fermented dairy products, LAB can produce a variety of metabolites with antibacterial, antifungal, anticancer, and probiotic properties. As a result, putative antimicrobialproducing $\mathrm{LAB}$ can be isolated from a variety of fermented milk products under various environmental circumstances [23]. Furthermore, the type of pathogen utilized, as well as the physical and chemical parameters employed under various environmental conditions, might affect the antibacterial activity of metabolites produced by antibioticproducing microbes [24].

In the current study, Lactobacillus, Lactococcus, Leuconostoc, Pediococcus, Streptococcus, and Enterococcus spp. were isolated and identified from fermented Ethiopian traditional dairy products. The presence of these genera is consistent with the findings of Mathara et al. [11]. It has been reported that traditional fermented milk favors the growth of LAB such as Lactobacillus, Lactococcus, Leuconostoc, Pediococcus, and Streptococcus spp. [25]. Mohammed et al. [26] also reported that Lactobacillus, Enterococcus, and Lactococcus spp. were the predominant species in Egyptian dairy products. This difference may accord with the change of study site, milk type, the season of production, and climate. In this study, all isolated and identified LAB strains were frequently found in various traditional fermented milk products of Ethiopia or in other parts of the world [11, 27].

In this study, the seven strains of CFS antibacterial effect were partially inactivated after being treated by $\alpha$-amylase and lysozyme enzymes, while the effect was slightly inactivated and retained in some strains after being treated with proteinase K and papain. Cocolin et al. [3] and Ren et al. [19] also demonstrated that the inhibitory effect of the bacteriocin isolated and produced by LAB from goat milk in India and homemade fermented foods in China is unstable after pepsin, trypsin, papain, and proteinase $\mathrm{K}$ enzymes are administered. These reports agreed with the results of this finding. This might be due to the antimicrobial substances of some strains that may contain organic compounds like carbohydrates that promote inhibition to some extent.

In the present study, after treating the CFS at different temperatures, their antimicrobial effect was effective and the CFS antibacterial activity of some strains (Z1, F2, and Z3) was reduced when the temperature was increased. Ren et al. [19] also demonstrated that the antimicrobial activities of the CFS were resistant to diverse temperature intervals. This might be due to their low molecular weight and chemically diverse secondary structures, which lead to the high-temperature resistance of most antibacterial compounds. This indicates that the antibacterial compounds produced by LAB could be used as biological preservatives for high-temperature treatments of food.

With regard to $\mathrm{pH}$, the antibacterial activities of the CFS were active and stable in acidic (2-6) environments. Also, some LAB strains (Z2, Z4, and N2) were active at $\mathrm{pH} 8$ but the antibacterial effect was reduced. This indicates the varying transport regulation and metabolism of the lactose system of LAB and the acid production ability of the different strains. The antagonistic effect of the CFS was completely lost at $\mathrm{pH} 10$ (alkaline condition), and this finding was inconsistent with Pinto et al. [14] and Ren et al. [19] who isolated LAB and lost its antibacterial activities at $\mathrm{pH} 12$ and 14, respectively. This implies that the main antibacterial effects of most strains are dependent on acid. As a result, Z2, Z4, and N2 strains of CFS were the most potent and could be used as a fermentation and biopreservative agent in milk and milk products between 2 and $6 \mathrm{pH}$ ranges.

The majority of LAB strains CFS were soluble in organic solvents such as methanol and ethanol. Avaiyarasi et al. [13] and Ren et al. [19] also displayed that the bacteriocin substances are soluble in organic solvents. As compared to ethanol, methanol treatment of CFS antibacterial effects of some strains was reduced. This was inconsistent with the findings of Ren et al. [19]. This might be due to the chemical structures of the antibacterial substances (CFS) secreted by LAB strains being intolerable to methanol solvent. LAB strains CFS showed a stable antibacterial effect against test strains after being treated with additives (potassium chloride and sodium citrate). Ren et al. [19] reported that the antibacterial activity of Lactobacillus spp. isolated in China from 
homemade fermented foods was effective when potassium chloride and sodium citrate additives were added.

In the present study, from a total of 97 isolates, only 7 strains displayed broad-spectrum antibacterial activities against Gram-positive and Gram-negative pathogenic bacterial strains. The CFS inhibition zone of the LAB isolates against test organisms ranges from 5 to $16 \mathrm{~mm}$ in diameter. According to the reports of Savadogo et al. [25], Esayas et al. [23], and Ren et al. [19], the inhibition zone of the CFS of $\mathrm{LAB}$ isolates against standard human pathogens ranged from 8 to $10 \mathrm{~mm}, 9$ to $11 \mathrm{~mm}$, and 7 to $9 \mathrm{~mm}$, respectively. Thus, the present result was a good inhibition zone $(5-16 \mathrm{~mm})$ as compared to the above findings while the current study result contradicts those of Rozila et al. [28] and Saleh [29], who isolated LAB from goat's milk and Egyptian traditional fermented milk products and recorded inhibition zones of $8-25 \mathrm{~mm}$ and $10-60 \mathrm{~mm}$, respectively, against test organisms. This difference might be due to the concentration and type of the produced antibacterial substances.

DÜndar [30] isolated Leuconostoc spp. that showed strong killing activity against several pathogenic bacteria, including Listeria monocytogenes, Bacillus cereus, and Pseudomonas aeruginosa. Furthermore, Sarika et al. [31] found that the CFS of Lactobacillus spp. inhibited the growth of Bacillus brevis, Bacillus pumilus, Bacillus subtilis, Escherichia coli, Pseudomonas aeruginosa, Staphylococcus aureus, Vibrio harveyi, Acinetobacter sp., and Arthrobacter sp. Additionally, Fazeli et al. [32] stated that the Lactobacillus strains could inhibit the growth of Salmonella sp. Bendali et al. [33] also demonstrated the antibacterial activity of CFS of Lactobacillus spp. against both Gram-negative (Pseudomonas aeruginosa, Klebsiella pneumoniae) and Gram-positive (Bacillus cereus, Enterococcus faecalis, and Staphylococcus aureus) bacterial pathogens. This finding also confirmed that the CFS of the LAB isolated from Ethiopian fermented milk products possessed broad-spectrum antimicrobial activity against food spoilage and pathogenic bacterial strains.

4.1. Limitations of the Study. Because of the COVID-19 pandemic and the lack of a SEM machine, HPLC analysis and purification of antibacterial substances, as well as the effect of CFS on pathogen cell morphology and intracellular organization, were not performed.

\section{Conclusions}

The present study demonstrated that the seven (Lactobacillus acidophilus, Lactobacillus paracasei, Lactobacillus plantarum, Lactobacillus rhamnosus, Leuconostoc mesenteroides, Streptococcus thermophilus, and Lactococcus lactis) LAB strains possessed an in vitro broad-spectrum antibacterial activity against food spoilage and pathogenic bacterial strains with an inhibition zone ranging from 5 to $16 \mathrm{~mm}$. The MIC and MBC values range from 0.10 to $0.30 \mu \mathrm{g} / \mu \mathrm{L}$ and 0.20 to $0.50 \mu \mathrm{g} / \mu \mathrm{L}$, respectively. After the treatment of the seven LAB metabolites with proteinase $\mathrm{K}$, papain, $\alpha$-amylase, and lysozyme, their antibacterial effect against test organisms was observed. Most LAB strains CFS antibacterial activity was highly resistant to heat $\left(45^{\circ} \mathrm{C}-100^{\circ} \mathrm{C}\right.$ ), acidity ( $\left.\mathrm{pH} 2-8\right)$, organic solvents (methanol, ethanol), and additives (potassium chloride, sodium citrate). Thus, the results of this investigation revealed that the LAB isolated from Ethiopian fermented traditional dairy products was a potent source of antibacterial metabolites with preservative potential. Thus, the isolation and characterization of LAB from fermented milk products of various geographical areas could be a useful source for the discovery of novel and chemically diverse compounds with a wide range of biological activities.

\section{Abbreviations}

ANOVA: Analysis of variance

CFS: Cell-free supernatants

LAB: $\quad$ Lactic acid bacteria

MBC: $\quad$ Minimum bactericidal concentration

MHA: $\quad$ Muller-Hinton Agar

MIC: $\quad$ Minimum inhibitory concentration

MRS: De Man, Rogosa, and Sharpe.

\section{Data Availability}

The data used to support the findings of this study are included in the paper and supplementary data.

\section{Disclosure}

The funding agencies had no involvement in the design of the study, data collection and analysis, interpretation of data, or writing the manuscript.

\section{Conflicts of Interest}

The authors declare that they have no conflicts of interest.

\section{Authors' Contributions}

The authors designed the project; AG and AA carried out the experiments, analyzed the data, and drafted and edited the manuscript. The authors have read and approved the final manuscript.

\section{Acknowledgments}

The authors are grateful to Microbiology Laboratory of Pawe Agricultural Research Center for providing the laboratory facilities. They also acknowledge Amhara Public Health Institute for providing the test bacterial strains. They also would like to thank all who were involved in this research.

\section{Supplementary Materials}

Supplementary data 1: agarose gel electrophoresis of the PCR product of the seven (line Z1-N2) strains. Supplementary data 2: antibacterial activities of F2, Z2, Z4, N2, and 
M1 potent $\mathrm{LAB}$ strains and Gentamicin (CN $10 \mu \mathrm{g} /$ disc) against food spoilage and pathogenic bacteria (A) S. aureus (ATCC $^{\circledR}$ 29213), (B) B. cereus (ATCC $\left.{ }^{\circledR} 11778\right), \quad(\mathrm{C})$ S. enteritidis (ATCC ${ }^{\circledR}$ 13076), (D) L. monocytogenes (ATCC ${ }^{\circledR}$ 7644), (E) P. aeruginosa (ATCC $\left.{ }^{\circledR} 27853\right)$, and (F) E. coli (ATCC $^{\circledR}$ 8739). (Supplementary Materials)

\section{References}

[1] T. Kabuki, H. Uenishi, M. Watanabe, Y. Seto, and H Nakajima, "Characterization of a bacteriocin, Thermophilin 1277, produced by Streptococcus thermophilus SBT1277," Journal of Applied Microbiology, vol. 102, no. 4, pp. 971-980, 2007.

[2] M. E. Stiles, "Biopreservation by lactic acid bacteria," Antonie van Leeuwenhoek, vol. 70, no. 2-4, pp. 331-345, 1996.

[3] L. Cocolin, R. Foschino, G. Comi, and M. Grazia Fortina, "Description of the bacteriocins produced by two strains of Enterococcus faecium isolated from Italian goat milk," Food Microbiology, vol. 24, no. 7-8, pp. 752-758, 2007.

[4] R. P. Ross, S. Morgan, and C. Hill, "Preservation and fermentation: past, present and future," International Journal of Food Microbiology, vol. 79, no. 1-2, pp. 3-16, 2002.

[5] M. A. Daeschel, "Antimicrobial substances from lactic acid bacteria for use as food preservatives," Food Technology, vol. 43, no. 1, pp. 164-167, 1989.

[6] B. t. Brink, M. Minekus, J. M. B. M. Van der Vossen, R. J. Leer, and J. H. J. H. i. t. Veld, "Antimicrobial activity of lactobacilli: preliminary characterization and optimization of production of acidocin B, a novel bacteriocin produced by Lactobacillus acidophilus M46," Journal of Applied Bacteriology, vol. 77, no. 2, pp. 140-148, 1994.

[7] L. Serna Cock and A. Rodríguez de Stouvenel, "Lactic acid production by a strain of Lactococcus lactis subs lactis isolated from sugar cane plants," Electronic Journal of Biotechnology, vol. 9, no. 1, p. 0, 2006.

[8] J. R. Tagg, A. S. Dajani, and L. W. Wannamaker, "Bacteriocins of gram-positive bacteria," Bacteriological Reviews, vol. 40, no. 3, p. 722, 2020.

[9] R. C. R. Martinez, M. Wachsman, N. I. Torres, J. G. LeBlanc, S. D. Todorov, and B. D. G. D. M. Franco, "Biochemical, antimicrobial and molecular characterization of a noncytotoxic bacteriocin produced by Lactobacillus plantarum ST71KS," Food Microbiology, vol. 34, no. 2, pp. 376-381, 2013.

[10] F. Miruts, "On-farm demonstration of improved rice (oryza sativa L.) varieties," Pawe Woreda of Metekel Zone, vol. 30, 2020.

[11] J. M. Mathara, U. Schillinger, P. M. Kutima, S. K. Mbugua, and W. H. Holzapfel, "Isolation, identification and characterisation of the dominant microorganisms of kule naoto: the Maasai traditional fermented milk in Kenya," International Journal of Food Microbiology, vol. 94, no. 3, pp. 269-278, 2004.

[12] J. M. Andrews and R. Wise, "Susceptibility testing of Bacillus species," Journal of Antimicrobial Chemotherapy, vol. 49, no. 6, pp. 1040-1042, 2002.

[13] N. Devi Avaiyarasi, A. David Ravindran, P. Venkatesh, and V. Arul, "In vitro selection, characterization and cytotoxic effect of bacteriocin of Lactobacillus sakei GM3 isolated from goat milk," Food Control, vol. 69, pp. 124-133, 2016.

[14] A. L. Pinto, M. Fernandes, C. Pinto et al., "Partial characterization of bacteriocins produced by Pediococcus pentosaceus and Enterococcus faecium isolated from ready-to-eat seafood," "Journal of Biotechnology, vol. 131, no. 2, pp. S220-S221, 2007.
[15] R. Islam, M. N. Hossain, M. K. Alam et al., “Antibacterial activity of lactic acid bacteria and extraction of bacteriocin protein," Advances in Bioscience and Biotechnology, vol. 11, no. 2, pp. 49-59, 2020.

[16] V. J. Boyle, M. E. Fancher, and R. W. Ross Jr, "Rapid, modified Kirby-Bauer susceptibility test with single, high-concentration antimicrobial disks," "Antimicrobial Agents and Chemotherapy, vol. 3, no. 3, pp. 418-424, 1973.

[17] M. Mohseni, H. Norouzi, J. Hamedi, and A. Roohi, "Screening of antibacterial producing actinomycetes from sediments of the Caspian Sea," International Journal of Molecular and Cellular Medicine, vol. 2, no. 2, pp. 64-71, 2013.

[18] J. G. Cappuccino and N. Sherman, Microbiology: A Laboratory Manual, Pearson Higher Ed, London, UK, 2013.

[19] D. Ren, J. Zhu, S. Gong, H. Liu, and H. Yu, “Antimicrobial characteristics of lactic acid bacteria isolated from homemade fermented foods," BioMed Research International, vol. 2018, Article ID 5416725, 9 pages, 2018.

[20] P. D. S. Malheiros, V. Sant, A. Brandelli, and B. D. G. D. M. Franco, "Kinetic modeling of thermal inactivation of antimicrobial peptides produced by Lactobacillus sakei subsp. sakei 2a," Thermochimica Acta, vol. 605, pp. 95-99, 2015.

[21] J. M. Andrews, "Determination of minimum inhibitory concentrations," Journal of Antimicrobial Chemotherapy, vol. 48, no. 1, pp. 5-16, 2001.

[22] Z. Ayana, M. Yohannis, and Z. Abera, "Food-borne bacterial diseases in Ethiopia," Academic Journal of Nutrition, vol. 4, no. 1, pp. 62-76, 2015.

[23] A. Esayas, B. Fekadu, and S. Amutha, "Isolation and characterizing of inhibitory substance producing lactic acid bacteria from Ergo, Ethiopian traditional fermented milk," African Journal of Microbiology Research, vol. 2, pp. 229-234, 2008.

[24] A. Bizuye, F. Moges, and B. Andualem, "Isolation and screening of antibiotic producing actinomycetes from soils in Gondar town, North West Ethiopia," Asian Pacific Journal of Tropical Disease, vol. 3, no. 5, pp. 375-381, 2013.

[25] A. Savadogo, C. A. Ouattara, I. H. Bassole, and A. S. Traore, "Antimicrobial activities of lactic acid bacteria strains isolated from Burkina Faso fermented milk," Pakistan Journal of Nutrition, vol. 3, no. 3, pp. 174-179, 2004.

[26] M. Mohammed, H. Abd El-Aziz, N. Omran, S. Anwar, S. Awad, and M. El-Soda, "Rep-PCR characterization and biochemical selection of lactic acid bacteria isolated from the Delta area of Egypt," International Journal of Food Microbiology, vol. 128, no. 3, pp. 417-423, 2009.

[27] A. Lelise, G. Belaynesh, M. Mulubrhan, S. Kedija, B. Endashaw, and B. Abebe, "Isolation and screening of antibacterial producing lactic acid bacteria from traditionally fermented drinks ("Ergo" and "Tej") in Gondar town, Northwest Ethiopia," Global Research Journal of Public Health and Epidemiology, vol. 1, no. 3, pp. 018-022, 2014.

[28] I. Rozila, S. Ezni, M. N. Lani et al., "Antibacterial activity of lactic acid bacteria isolated from goats milk," in Proceedings of the International Annual Symposium On Sustainability Science And Management, pp. 09-11, Malaysia, December 2012.

[29] F. A. Saleh, "Isolation and identification of microorganisms and antibacterial activity of Laban Zeer, an Egyptian traditional fermented milk product," Scientific Journal of Microbiology, vol. 2, no. 2, pp. 31-42, 2013.

[30] H. Dündar, Characterization and Purification of a Bacteriocin Produced by Leuconostoc Mesenteroides Subsp. Cremoris, Springer, Berlin, Germany, 2006. 
[31] A. R. Sarika, A. P. Lipton, and M. S. Aishwarya, "Bacteriocin production by a new isolate of Lactobacillus rhamnosus GP1 under different culture conditions," Advance Journal of Food Science and Technology, vol. 2, no. 5, pp. 291-297, 2010.

[32] M. R. Fazeli, E. Vaghari, H. Jamalifar, Z. Ebrahim, and N. Samadi, "Antimicrobial activity of Lactobacillus plantarum strains isolated from fermented olives origin," Journal of Medicinal Plants, vol. 3, no. 31, pp. 14-18, 2009.

[33] F. Bendali, N. Madi, and D. Sadoun, "Beneficial effects of a strain of Lactobacillus paracasei subsp. paracasei in Staphylococcus aureus-induced intestinal and colonic injury," International Journal of Infectious Diseases, vol. 15, no. 11, pp. e787-e794, 2011. 